\title{
Human Resources Empowerment, Working Motivation and Organization Change in Improving Hotel Business Performance in Bali
}

\author{
Gusti Kade Sutawa, I Komang Gde Bendesa and I Nyoman Madiun
}

\author{
School of Postgraduate Study \\ Doctorate Degree in Tourism Udayana University
}

Coressponding author: gustikadesutawa@yahoo.com

\section{ARTICLE INFO}

Received

20 February 2014

Accepted

02 August 2014

Available online

10 September 2014

\begin{abstract}
This study aims to test and analyze impact of human resource development on working motivation of hotel business workers in Bali, impact of human resource development on organizational changes of hotel business in Bali, impact of human resource development on the performance of hotel business in Bali, impact of working motivation against organizational changes in hotel business in Bali, impact of working motivation on the organizations performance of the hotel business in Bali, and impact of organizational changes against organizations performance of the hotel business in Bali. There were 170 respondents of star-rated hotel employees which were selected through purposive sampling technique. Structural Equation Modeling with the application Analysis of Moment Structure was used to analyze the data. The results show that empowerment of human resources (HR) has positive and significant impact on working motivation, organizational changes, and the organization performance of hotel business in Bali, working motivation has positive and significant impact on organizational changes and the organization performance of hotel business in Bali and organizational changes have significant and positive impact on the organization performance of hotel business in Bali. Empowerment variables have the most powerful impact to support the improvement of organizational performance, followed by organizational changes and working motivation variables. The results indicate that human resource empowerment improves the performance of the hotel business in Bali. Therefore, human resource development need to be prioritized in order to improve organizational performance of star hotels in Bali.
\end{abstract}

Keywords: human resource empowerment, working motivation, organizational changes, organizational performance.

\section{Introduction}

\section{Background}

The dynamics of organizational management sector of tourism businesses in Bali is generally associated with the era of globalization. The era of globalization is characterized by the presence of free competition that requires organization and rational fast action and requires the role of various components such as human resources, technology, and legal instruments so that organizational goals can be achieved. In line with today's era of tourism globalization, tourism industry will evolve into a thriving industry in the future. This has important value to the creation of employment and foreign exchange earnings. When the economy grows the level of income will also increase. Most of the revenue comes from the tourism industry, especially in the developing countries (WTO, 2007). 
Bali is one of the famous tourist destinations in the world. Several awards have been awarded, to this island, among others, The Best Island in Asia Pacific by Leisure Magazine and Luxury Travel Magazine published in London (2007); The Best Island in Asia Pacific by the Destin-Asia magazine Hong Kong (2009); "Island Destination of the Year" in the event of China Travel and Meetings Industry Award, 2013; and appreciation of World Best Awards 2014 in the category of The Best Island in Asia from magazine of international tourism version, "Travel + Leisure". Some of these awards have influence positively to the number of tourist visits. Travelers who come will stay for a while in Bali. The average length of stay of tourists in Bali in the recent years is quite high, i.e. more than 9 days for foreign tourists and more than 3-4 days for tourists domestic. Up to the year of 2014, there are 3.039 units of accommodation facilities in Bali with 61.025 rooms. Most rooms (48\%) are star hotels, the remaining $40 \%$ are of non-star hotel rooms, and $12 \%$ are home stay rooms.

The background of this study is due to the fact that Bali has an excess of accommodation. In the last 4 years (years 2010-2014), the number of hotel rooms / inns in Bali increased by $34 \%$, from 45.408 rooms in 2010 to 61015 rooms in 2014 (Bali Provincial Tourism Office, 2014).

The increasing number of hotel rooms in Badung in the period 2011-2014 has led to a price war that hotel room prices fell. In some hotels, room rates were initially sold at prices ranging from IDR. 500,000 - up to IDR. 750,000 reduced to IDR. 250,000 - IDR. 350,000 . It is considered by some parties as the phenomenon of unhealthy tourism businesses because in the long run it will hurt employers because the travel accommodation services re-investment value (return of investment / ROI) will be very difficult. The increasing number of hotel rooms that lead to the hotel room occupancy rate decreased. With the decline in hotel room occupancy, automatically the service charge received by the hotel employees was also decreased, in turn causing the employee motivation decreased and performance of the hotel also declined. The management of the hotel needs to anticipate problems related to the needs of

http://ojs.unud.ac.id/index.php/eot professional human resources, the need for increased skills and motivation of human resources, as well as creative hotel product marketing breakthrough using online media. Empowerment of human resources and increase employee motivation are done for the organizational changes that occur can improve organizational performance of services business in the hospitality sector of Bali. The research reported in this dissertation deliberately done in star (III, IV, and V) hotels in Bali in the hope that the study results are useful for the development of the hospitality business in all regencies / cities in Bali. In addition, this study is expected to produce recommendations for the government in determining the investment policy in the hospitality services sector throughout Bali.

\section{Research Objectives}

This study aims to examine and analyze problems of management organizations in hospitality services sector relating to empowerment of human resources, working motivation, organizational changes and organizational performance of hotel business in Bali. Specifically this study aims to assess and analyze:

1) The effect of empowerment of human resources for employee working motivation, organizational change, and organizational performance hospitality business in Bali,

2) The effect of working motivation on organizational changes, and organizational performance of hospitality businesses in Bali,

3) The effect of organizational changes on the performance of the hospitality business organization in Bali.

\section{Literature Review}

\section{Previous Studies}

Some studies related to the development of the hospitality business management have been done, especially concerning human resource development, motivation, and performance of the company. First, the study conducted by Suaedi (2005) about the organizational structure, innovation and organizational performance. It was concluded that the organizational structure had 
significant positive direct effect on organizational innovation and organizational performance.

Second, Rispati et al. (2013) examines the link between training and employee performance in Semarang. The study, conducted at the Hotel Grasia Semarang, shows that vocational training has the greatest influence on the performance of employees is $10.1 \%$ compared to the motivation that only $5 \%$. The combination of job training and motivation has an influence on employee performance by $13.3 \%$.

Third, research carried out by Arimbawa and Dewi (2013) involving 64 samples in hotel Jimbaran Puri Bali. Evaluative study on the performance of the employees of this hotel shows that $92.4 \%$ of employee performance of Jimbaran Puri Bali hotel is influenced by organizational culture, leadership style, and working motivation.

Fourth, the study conducted by Triatmanto et al. (2010) describes the positive relationship between the empowerment of human resources and organizational performance. From the studies conducted in 34 star hotels in East Java, it is concluded that the performance of hotels is affected by the empowerment of human resources, namely their participation in achieving the goals, commitment, authority and responsibility in decision making.

\section{Theoretical Basis}

In general, this dissertation studies the topic of management of hospitality business services in Bali. Some grounding theoretical concerns empowerment of human resources, motivation, organizational changes, and organizational performance.

\section{Empowerment of Human Resources}

Human resources have a very central role in an organization. Human resources must be managed properly and is part of the duty of managers to achieve organizational success (Nawawi, 2005; Rachmawati, 2008; Rowley and Jackson, 2012). According to Noe et al. (in Rokhman, 2002), the empowerment of human resources includes six indicators as follows: (1) provide an opportunity for employees to participate in policy making and determine the success of the company, (2) delegate important tasks to subordinates, (3) provide awards to staff / employees who excel, (4) provide for recognition of the existence of staff / employees, (5) creating an open communication system so as to create mutual understanding between employees and management, (6) maintain the credibility of the organization with the award and to develop a working environment which encourages healthy competition so as to create high organization performance.

\section{Motivation of Human Resources}

Motivation can be defined as an inner force that drives individuals to achieve personal and organizational goals (Lindner, 1998). Psychologists and economists have long studied what changes could lead to a lasting improvement in the quality of work and employee satisfaction. They try to explain what motivates people to achieve success not only for themselves but also for the company (Ramlall, 2004). Gibson et al. (1994) argued Three Needs Theory from McClelland (1973) as follows.

(1) The need for achievement (need for achievement), namely the desire to do something better than the previous one.

(2) The need for affiliation (need for affiliation), namely the need to be liked, develop or maintain friendships with others.

(3) The need for power (need for power), namely the need for a stronger, more influential on others.

\section{Organizational Changes}

In accordance with the challenges of globalization, an organization / company can survive if it can make changes, including changes in the hospitality business organizations in Bali. Sobirin (2005) stated that there are two factors driving the change, i.e. external factors such as changes in technology and the increasing integration of international economic organizations as well as internal factors which include two main things: (1) changes in the organization hardware (hard system tools) or commonly called with structural changes, which include changes in strategy, organizational structure 
and systems, and (2) changes in organization software (soft system tools) or cultural changes that include changes in human behavior in organizations, human resource policies and organizational culture. In general, changes in the Bali hospitality organization in accordance with the formula Robbins (2003) includes four indicators: (1) changes in the organizational structure, (2) changes in organizational strategy, (3) changes in human resource management, and (4) the application of assistive technologies organizational change.

\section{Organizational Performance}

In essence, the performance is a result of a work achieved in carrying out the tasks assigned to him based on skills, experience and sincerity as well as time (Hasibuan, 1990). Performance is the result of work achieved by a person in carrying out the tasks assigned to him in accordance with defined criteria. Individual performance will affect the performance of the organization / company. The company's performance is the result of work by the quality and quantity can be achieved by an employee in carrying out duties in accordance with responsibilities given to him (Mangkunagara, 2006). The company performance variables are operationally measured using four indicators adopted from Brahmasari (2004), namely: (1) the ability of the company to improve the efficiency of its human resources, (2) the ability of the company to improve the efficiency of the use of all time allocated, (3) the company's ability to adapt to changes, and (4) the company's ability to achieve the set targets.

\section{Hypotheses}

Performance of hospitality business organizations is associated with different variables, i.e. the variables empowerment of human resources, working motivation and organizational change variables. Based on respondents' perceptions of the research variables in this study there are six proposed hypothesis.

H1: Empowerment of human resources effects significant and positive on the motivation of employees working in hotel business in Bali.
H2: Empowerment of human resources effects significant and positive on the hotel business organizational change in Bali.

H3: Empowerment of human resources effects significant and positive on the performance of the hotel business organization in Bali.

H4: Working motivation effect positive and significant on the hotel business organizational change in Bali.

H5: Motivation effects positive and significant on the performance of the hotel business organization in Bali.

H6: Organizational change effects significant and positive on organizational performance variables of hotel business in Bali.

\section{Methodology}

The population of this study is employee of star hotels throughout Bali. In accordance with Structural Equation Modeling (SEM) modeling, total samples of 170 respondents have been taken through purposive sampling technique. The process of data collection is carried out through several techniques, namely: (1) a questionnaire filled out by the respondents; (2) Study the documentation, reviewing the literature in the form of books, journals, policy documents (laws and regulations) and other literature related to the topic of the research, (3) observation participation, namely direct observation of researchers in the field of the studies reviewed issues; (4) in-depth interviews involving 13 informants coming from stakeholders (policymakers) in the field of tourism, tourism observers and practitioners of hospitality (tourism) in Bali, and (5) Focus Group Discussion (FGD) followed by 18 hotel managers and supervisors that aims to explore specific issues related to the topics discussed.

The data collected through questionnaires were analyzed by using structural equation modeling analysis technique SEM (Structural Equation Modeling) assisted by the applications of Analysis of Moment Structure (AMOS) version 18. SEM analysis technique is applied to test the proposed research hypothesis. After the data were analyzed by structural equation modeling (Structural Equation Modeling or SEM), the triangulation was applied, i.e. validation, enrichment and 
deepening further data, including data resulting from focus group discussions, interviews, and field observations. All the collected data were analyzed by applying the theory of human resource development, the theory of working motivation, organizational change theory and the theory of organizational performance.

\section{Results and Discussion}

\section{Overview of Star Hotel Management in Bali}

Until the end of year 2014, the number of star hotels in Bali is as many as 217 units and 3463 rooms. Most of the star hotels buildings in Bali are located in the district of Badung. There are two districts that have not had star hotels, namely district of Bangli and Jembrana. In general, the organizational structure of star hotels is headed by a general manager who is assisted by several mid-level managers that are divided into several departments. The Model of Star Hotel Organizational Structure is diverse. In general, the organizational structure of star hotel includes five up to seven departments.

\section{Characteristics of Respondents}

Respondents who were included in this study amounted to 170 people. They are hotel workers who come from 95 star hotels (III, VI, and V) in Bali which were selected as the study sample. According to gender, respondents were male sex as much as $54.71 \%$ and $45.29 \%$ female. In terms of age groups, the majority of respondents aged $31-40$ years (43.53\%), followed by respondents in the age group 21-30 years (31.76\%), 41-50 years $(21.76 \%), 51$ up $(2: 35 \%)$ and $15-20$ years $(0.59 \%)$.

Seen from the educational background, the majority of respondents $(67.06 \%)$ have completed college-level education / diploma, followed by respondents who get SMA / equal education back ground (18.24\%) and as much as $14.71 \%$ have graduated from college. From this data, it is known that the majority of staff / employees of the hotel used as respondents are well-educated workers from college-level educational institutions / diploma, including educational institutions academy of hospitality and tourism.
Based on the time period or tenure, most respondents $(57.65 \%)$ had been on the job as hotel worker for 2-4 years, followed by respondents who worked at the hotel for 5-9 years $(18.24 \%)$ and 1 year $(7.06 \%)$. Most of the respondents claimed to have worked as a hotel employee in a relatively long period of time, namely $10-15$ years $(7.65 \%)$, even more than 15 years $(9.41 \%)$.

Most of the respondents work in the front office $(36.47 \%)$, followed by respondents who work in the human resources $(20.00 \%)$, food and beverage (18.24\%), housekeeping $(12.35 \%)$, accounting (Financial) $(9.41 \%)$ and sales / marketing (3.53\%). Of the 170 respondents who filled out a questionnaire, also known that most of them $(70.59 \%)$ claimed to earn a basic salary between IDR 1 , 5 million up to IDR. 3 million, followed by the response obtaining basic salary of IDR 1 million - IDR 1.5 million (14.71\%), basic salary of more than IDR 3 million (13.53\%), as well as the basic salary is below IDR. 1 million $(1.18 \%)$.

\section{Analysis Results of Full SEM Model}

After the measuring models were analyzed through Confirmatory Factor Analysis and seen that each variable can be used to define a latent constructs, then a fullSEM models can be analyzed. Results of data processing with the AMOS program can be seen in Figure 1.

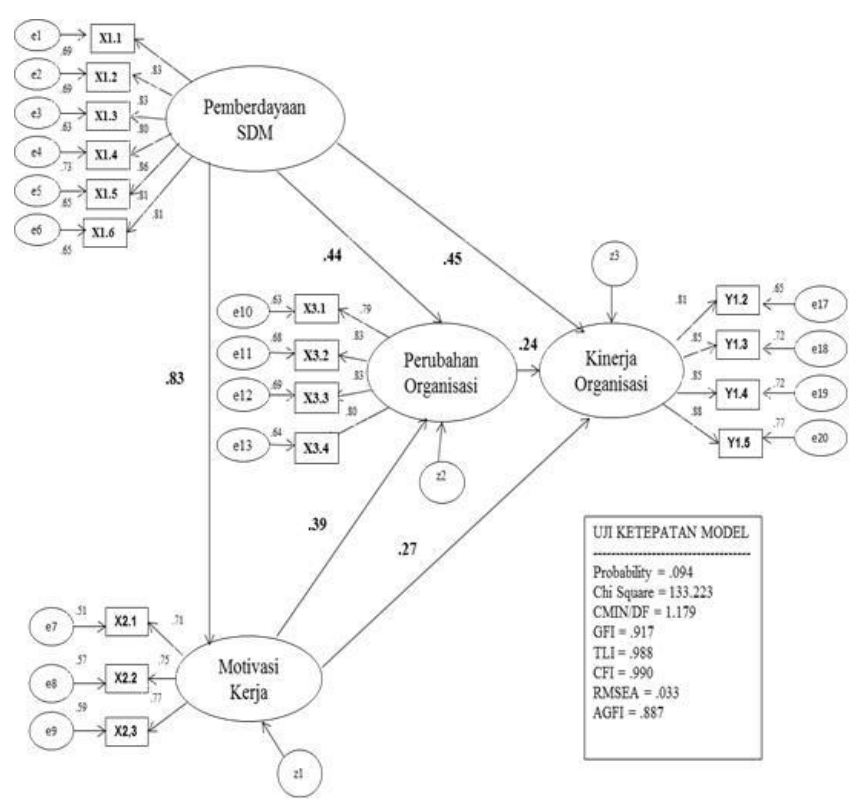

Figure 1. Structural Equation Model 
The results of testing the suitability of the model in Figure 5.1 shows the value of chi square as much as 133.223 and the value of the probability value of 0.94 which is above the limit of its significance 0.05 . In addition, an index measuring the value of suitability models, which include GFI (0.917), AGFI (0,887), TLI (.988), CFI (0.990), RMSEA (0.033), and CMIN / DF $(1,179)$ are in the range of expected values (Table 5.1). All this shows that there is no difference between the sample covariance matrix and population covariance matrix estimated so full model SEM is acceptable.

Table 1. Structural Equation Model Testing Results

\begin{tabular}{|l|l|l|l|}
\hline $\begin{array}{l}\text { Goodness of } \\
\text { Fit Measure }\end{array}$ & $\begin{array}{l}\text { Critical } \\
\text { Value } \\
\text { (Cut off } \\
\text { Value) }\end{array}$ & $\begin{array}{l}\text { Results } \\
\text { Model } \\
\text { of }\end{array}$ & $\begin{array}{l}\text { Evaluation } \\
\text { Model }\end{array}$ \\
\hline $\begin{array}{l}\text { Chi Square } \\
(\lambda 2)\end{array}$ & $\begin{array}{l}\text { Expected } \\
\text { small }\end{array}$ & 133.223 & Good \\
\hline $\begin{array}{l}\text { Signifikance } \\
\text { Probability } \\
\text { (p) }\end{array}$ & $\geq 0,05$ & 0,094 & Good \\
\hline RMSEA & $\leq 0,08$ & 0,033 & Good \\
\hline GFI & $\geq 0,9$ & 0,917 & Good \\
\hline AGFI & $\geq 0,9$ & 0,887 & Enough \\
\hline CMIN/DF & $\leq 2,00$ & 1.179 & Good \\
\hline TLI & $\geq 0,95$ & 0,988 & Good \\
\hline CFI & $\geq 0,94$ & 0,990 & Good \\
\hline
\end{tabular}

Source: developed from this research

\section{Effect of Human Resource Empowerment against Working Motivation}

Empowerment of human resources (HR) is a change in strategy that aims to improve individual and organizational performance. As stated by Noe et al. (2004), there are six indicators of human resource development which contribute to increase the motivation of the hotel staff here, namely: (1) the involvement of the workforce, the level of labor involvement in the development of the company, (2) the delegation of tasks, namely level delegation of tasks to the work force for the progress of the company, (3) awards for workers, the level of the award given to the labor organization achievement, recognition of the achievements of labor, i.e., the level of recognition and awards given to labor organizations achievers, (5) the existence of open communication, namely the

http://ojs.unud.ac.id/index.php/eot level of open communication both among workforce as well as between labor and management and owners of the hotel, and (6) the credibility of the organization, namely credibility level of leadership of the organization.

The management / operator of star hotels in Bali implement the above six indicators in empowering workers. The workforce is involved as a compact team work in the development of the company. The process of delegating tasks in accordance with the competence of each worker is also applied. The management of the hotel also presented awards to outstanding workforce, provide recognition for the achievements of labor, and implement a system of open communication, good communication among workforce and between labor and management and hotel owners. Moreover, as an organization, management backed up by the entire workforce strives to maintain credibility of the organization.

Table 2. Structural Model Hypothesis Test Results

\begin{tabular}{|c|c|c|c|c|c|}
\hline $\begin{array}{l}\text { Hypo } \\
\text { theses }\end{array}$ & Direction Line & $\begin{array}{l}\text { Regr } \\
\text { essio } \\
\mathrm{n} \\
\text { Coef } \\
\text { ficie } \\
\text { nts }\end{array}$ & $\begin{array}{l}\text { C.R } \\
\text {. }\end{array}$ & $\begin{array}{l}\text { p- } \\
\text { va } \\
\text { lu } \\
\text { e }\end{array}$ & $\begin{array}{l}\text { Coeff } \\
\text { icient } \\
\text { stand } \\
\text { ard }\end{array}$ \\
\hline H1 & $\begin{array}{l}\text { Human Resources } \\
\text { Empowerment } \rightarrow \\
\text { Working } \\
\text { Motivation }\end{array}$ & 0.799 & $\begin{array}{l}9.1 \\
38\end{array}$ & $\begin{array}{c}0 . \\
00 \\
0\end{array}$ & 0.830 \\
\hline $\mathrm{H} 2$ & $\begin{array}{l}\text { Human Resource } \\
\text { Empowerment } \rightarrow \\
\text { Organization } \\
\text { Change }\end{array}$ & 0.404 & $\begin{array}{l}3.0 \\
23\end{array}$ & $\begin{array}{c}0 . \\
00 \\
3\end{array}$ & 0.440 \\
\hline H3 & $\begin{array}{l}\text { Human Resources } \\
\text { Empowerment } \rightarrow \\
\text { Organization } \\
\text { Performance }\end{array}$ & 0.562 & $\begin{array}{l}3.7 \\
87\end{array}$ & $\begin{array}{c}0 . \\
00 \\
0\end{array}$ & 0.450 \\
\hline $\mathrm{H} 4$ & $\begin{array}{l}\text { Working } \\
\text { Motivation } \rightarrow \\
\text { Organization } \\
\text { Change }\end{array}$ & 0.377 & $\begin{array}{c}2.5 \\
60\end{array}$ & $\begin{array}{c}0 . \\
01 \\
0\end{array}$ & 0.395 \\
\hline H5 & $\begin{array}{l}\text { Working } \\
\text { Motivation } \rightarrow \\
\text { Organization } \\
\text { Performance }\end{array}$ & 0.350 & $\begin{array}{c}2.0 \\
91\end{array}$ & $\begin{array}{c}0 . \\
03 \\
7\end{array}$ & 0.269 \\
\hline H6 & $\begin{array}{l}\text { Organization } \\
\text { Change } \rightarrow \\
\text { Organization } \\
\text { Peformance }\end{array}$ & 0.323 & $\begin{array}{c}2.5 \\
19\end{array}$ & $\begin{array}{c}0 . \\
01 \\
2\end{array}$ & 0.238 \\
\hline
\end{tabular}

Source: developed from this research 
Results of testing hypothesis 1 (H1) indicates that the empowerment of human resources (HR) proved positive and significant effect on work motivation hospitality industry workers in Bali. Empowerment direct influence on work motivation of human resources reflected in the results $\mathrm{p}$-value less than 0.05 , and the value of the raw coefficient (standardize coefficient) of 0.830 . By looking at the value of loading factor (the raw coefficient) of 0.830 , the efforts of human resource development has a positive influence for the improvement of employee motivation of the hotels by $83 \%$ (Table 5.2). To that end, the improvement of employee motivation of star hotels in Bali can be done through the empowerment of human resources. The more intensive the empowerment efforts, the higher workforce motivation of star hotels in Bali will be. Conversely, the weaker the efforts of empowerment done, the less their motivation will be.

Human resource development managed to increase employee motivation of star hotels in Bali. This is in accordance with the David McClelland Three Needs Theory that human needs include three things, namely the achievement needs (need for achievement), namely the desire to do something better than before, the motivation of individuals to be willing to work hard and creativity in his work; need for affiliation (need for affiliation), namely the need to be liked, develop or maintain friendships with others, and the need for power (need for power), namely the need for a stronger, more influential on others, have power or position in certain company (Gibson et al., 1994; Saydam, 2005).

The Human resource development to increase the motivation of the staff in accordance with the results of Rispati, Hadi and Rodhiyah (2013) research is that the job training has the most impact on employee performance. Human resources (HR) have a central role and need to be well managed to achieve organizational success today and in the future (Nawawi, 2005; Rachmawati, 2008; Rowley and Jackson, 2012). Human resource development is demanding the expansion of the role, authority and power, and increased flexibility on how the roles were performed (Sedarmayanti, 2001; Jarrar and Zairi, 2002; Chew, Cheng and Petrovic-Lazarevic, 2006;

http://ojs.unud.ac.id/index.php/eot
Stewart and O'Donnell, 2007; Suwatno and Priansa, 2011; Rispati, Hadi and Rodhiyah, 2013).

\section{Effect of Human Resource Empowerment on Organizational Change}

The results of testing hypothesis $2(\mathrm{H} 2)$ suggests that human resource development proved positive and significant impact on the hotel business organizational change in Bali. It is supported by a p-value that is less than 0.05 and the value of direct influence (standardize direct effect) human resource development to organizational change by 0.440 and the value of indirect influence (standardize indirect effect) of human resource development to organizational change of 0.328. Human resource development affects the organizational changes of star hotel business services sector in Bali. The direct effect of human resource development to organizational change of 0.440 indicates that the human resource development efforts contribute to organizational change by $44 \%$. Organizational change of star hotels in Bali can be done through empowerment of its workforce. In accordance with Robbin conception (2003), organizational change of star hotels in Bali includes four indicators, namely: (1) changes in the organizational structure, (2) changes in organizational strategy, (3) changes in human resource management, and (4) the application of technology supporting organizational change.

The results also support the research conducted by (Lashley, 1999; Alwi, 2001; Kotter and Cohen, 2002; Taplin, 2006; Lam et al., 2011) which concluded that human resource development is a key factor in making organizational changes by adjusting the speed of the changes occurring in the external organization. Empowerment of HR becomes a trigger and drive organizational change. However, these results differ from the opinion of Hannan and Freeman (1984), that human resource development is less significant in organizational change. According to them that organizational change is a consequence of a developmental process rather than as an option. Capacity building of $\mathrm{HR}$ and the organization is the most appropriate way to support the organizational changes that have been planned and are used 
to implement change strategies to improve organizational performance.

\section{Effect of Human Resource Empowerment on Organizational Performance}

Results of testing hypothesis 3 (H3) showed that the empowerment of human resources effect significant and positive on the performance of the hotel business organization in Bali. This is indicated by the value of coefficient loading raw (standardize coefficient) of 0.450 . The influence of human resource development to organizational performance of 0.450 indicates that the human resource development efforts contribute to organizational performance by $45 \%$. Efforts to improve organizational performance of star hotels in Bali can be done through empowerment of its workforce.

The performance of the organization is the attainment of organizational goals that can take the form of quantitative and qualitative output, creativity, flexibility unreliable or other things desired by the organization. Organizational performance can be realized in the form of an increase in achievement of the target occupancy. This is in accordance with Robbins opinion of (2003), which suggests that human performance is the output that can be measured on productivity, absenteeism, turnover, citizenship and satisfaction. In this research, organizational performance indicators include: (1) the efficient use of human resources, the level of ability of the company to streamline the use of human resources, (2) efficient use of time, the company's ability to streamline the level of utilization of time, (3) the ability to adapt to changes, namely the level of enterprise adaptation to changes that occur, and (4) the ability to hit the target company, the company's ability to achieve the level of achievement of hotel room occupancy.

In the last four years (years 2010-2014) the number of hotel rooms / inns in Bali increased by $34 \%$ (from 45.408 rooms in 2010 to 61.015 rooms in 2014). The rapid development in Bali has resulted in an excess number of rooms which further raises a variety of issues. Among these is the emergence of unfair competition in the determination of hotel room rates, performance of star hotels in Bali are less optimal. In an effort to maintain the organization's the optimal hotel performance in Bali, FGD and all informants recommend that restrictions on the number of hotel rooms and dismiss temporarily the construction of new hotels in Badung and Denpasar city should be urgently done. Restriction on building hotels in Bali is also part of the strategy of the Bali Provincial Government in implementing sustainable tourism development by involving widespread participation. Participation of society could be built if the community empowerment is done. Community empowerment is the key factor in the development of tourism because of the empowerment, the community will participate in maintaining attraction, and namely, the potential of their cultural and natural potential so that ultimately the development of sustainable tourism can be achieved (Sutawa, 2012).

Theoretically, the findings of this study support the theory of Noe et al. (2003) which states that human resource development affect the success of the company's management. The results of this study also support some of the results of previous studies, among others by Lashley (1999); Jarrar and Zairi (2002); Kotter and Cohen (2002); Suaedi (2005); Rose and Kumar (2006); Triatmanto et al. (2010). Human resource development has become an alternative for the development of the organization and strategies to improve organizational performance.

\section{Effect of Working Motivation toward Organizational Change}

Working Motivation is a process that encourages, directs and maintains human behavior towards the achievement of organizational goals. Labor motivation can be developed if the company gives awards for job performance, responsibilities, involvement of the entire workforce, and the company's commitment to employee career advancement. Working motivation variable includes three indicators, namely (1) the motivation of workers to improve their performance, (2) the motivation of workers to be liked and make friends with others, and (3) the motivation of workers for the ruling (to have positions in his company). 
Results of hypothesis 4 (H4) testing indicated that working motivation effects positive and significant on the hotel business organizational change in Bali. This conclusion is supported by a p-value less than 0.05 and the value of direct influence (standardize direct effect) efforts to increase working motivation on organizational changes by 0.395 . Statistical test results prove that the organizational changes of star hotels in Bali affected by efforts to increase employee motivation of entire workforce by $40 \%$. The direct effect of work motivation to organizational changes show relatively low, at $40 \%$. However, if seen from the average value of the respondents' assessment of the working motivation of 4.03 with a standard deviation of 0.741 , then the respondent's assessment indicates that overall respondents tend to give higher response to the statements indicator variable of working motivation.

The increase in labor motivation can influence changes in business organization of hospitality services in Bali. This is consistent with the results of Jarrar and Zairi (2002); Taplin (2006); Stewart and O'Donnell (2007); Lam et al. (2011); Arimbawa and Dewi (2013), as well as Luekitinan (2014) associated with responsibility, workers' participation and authority. Improvement of motivation fosters responsibility and worker participation in managing the organization. Furthermore, the growth of motivation as a result of human resource development will motivate a person to more advanced, achievement, has the authority and power to the company's progress.

\section{Effect of Work Motivation for Organizational Performance}

The results of (H5) hypothesis 5 testing showed that working motivation effects positive and significant on the performance of the organization of hotel business in Bali. It is supported by a p-value less than 0.05 and the value of direct influence (standardize direct effect) working motivation on organizational performance and value of 0.269 indirect effect (standardize indirect effect) working motivation on organizational performance by 0.094. Statistical test results indicate that efforts to increase the motivation of hotel staff / employees directly affect on the performance of the organizations of star hotel accommodation service sector in Bali by $27 \%$, and efforts to increase the motivation of staff $/$ hotel employees indirectly affect the performance of the organization of star hotels accommodation services sector in Bali of $0.9 \%$.

Contributions of working motivation on the performance of a relatively small organization take place because working motivation has not become the dominant factor for improving performance. However, motivation is still needed to support the organization's efforts to improve the performance of the hotel business in Bali. According to the results of focus group discussions and in-depth interviews, motivation contributes relatively little to the performance of society together because motivation is commonplace (common) and become a basic requirement for all employees of the hotel in order to carry out its work in accordance with job description and standard operating procedures. Motivation and employee morale can be maintained with optimal if their basic rights such as salaries, incentives and other rewards are met. Motivation does not necessarily improve the performance of the organization because there are other factors, including marketing strategy factors, marketing network and limited authority of employees in improving organizational performance.

In general working motivation in the staff / employee of star hotels in Bali is conducted, among others, in the form of giving appropriate rewards and special attention to them. The management of the hotel also provides an opportunity for employees to improve job performance, as well as supporting them to build his career (career development) according to the available opportunities. The results are consistent with previous studies conducted by Taplin (2006); Usman (2006); Lam et al. (2011); Arimbawa and Dewi (2013); Muogbo (2013); Rispati, Hadi and Rodhiyah (2013) which concluded that efforts to increase working motivation significantly affect the company's performance. With a strong motivation of the workforce will provide full participation to the advancement and improvement of organizational performance. 


\section{Influence of Organizational Changes towards Organizational Performance}

Organizational change is an organization's ability to respond and adapt to the changing demands both a result of external and internal factors. Changes in the organization include structures, strategies, human resources and technology. Organizational changes carried out as a form of organizations response to advocate for improvements to the organization's ability to adapt to environmental changes and to seek changes in employee behavior.

In accordance with Robbins (2003), organizational change includes four indicators, namely: (1) changes in the organizational structure, the adjustment of the organizational structure for the advancement of the company, (2) changes in the organization's strategy, namely the development of the organization's strategy for advancement of the company, (3) Changes in human resources management, the human resources management changes for the betterment of the company, and (4) the application of technology supporting organizational change, namely the application of technology to support the company's progress. The results of hypotheses 6 (H6) testing show that organizational change effect positive and significant on the performance of the hotel business organization in Bali. This conclusion is supported by a p-value less than 0.05 and the value of direct influence (standardize direct effect) organizational changes on organizational performance by 0.238. This condition proves that organizational change efforts can influence performance of organizations levels of hospitality business service sector in Bali of $24 \%$.

The contribution of organizational changes to organizational performance is relatively small. According to the FGD, the contribution of this organizational change is relatively small because of organizational change is not a major factor for the increase in the performance of hospitality business services sector in Bali. Organizational change is a necessity to anticipate the hospitality business competition in today's global era, including the adjustment of organizational structure (additional revenue position of manager and e-commerce). Although not a dominant factor, organizational change is still needed to support the improvement of organizational performance of hotel business in Bali. To that end, efforts to improve organizational performance of star hotels in Bali one of which can be reached through organizational change.

The results of this study support the research conducted by Lashley (1999); Jarrar and Zairi (2002); Kotter and Cohen (2002); Suaedi (2005); Chew, Cheng and PetrovicLazarevic (2006); Rose and Kumar (2006); Lam et al. (2011); Thomas (2014) that changes in the organizational structure influence on organizational innovation and organizational performance.

\section{Effect of human resources Empowerment, Working Motivation and Organizational Changes to Organizational Performance}

Hospitality business in Bali continues to improve its performance. Organizations Performance of hospitality business in this research include: efficient use of human resources, efficient use of time, the ability to adapt to changes, and the company's ability to achieve its targets that have been set, namely the level of sales of hotel rooms (Brahmasari, 2004). Of the respondents' assessment towards the research inter-variable relationship is known that jointly together human resource development, motivation and organizational changes have implications for efforts to improve organizational performance of star hotels in Bali. This is evidenced by the existence of influence between variables as follows.

1) The direct effect of human resource development variables on the performance of the organization by $45 \%$, and the indirect influence of human resource development variables on the performance of the organization by $41 \%$ through working motivation and organizational change, so that the total effect of human resource development to organizational performance reach $86 \%$.

2) The direct effect of working motivation to organizational performance through organizational change variables by $27 \%$ and indirect effects of working motivation 
to organizational performance through organizational change variable by $09 \%$ so that the total effect of working motivation on organizational performance reach $36 \%$.

3) The direct effect of organizational change variables on the performance of the organization by $24 \%$.

From the results of statistical tests on the relationship between the variables above, it appears that the most influential variable is the dominant variable of human resource development to organizational performance, while the weakest variables are variables of working motivation to organizational performance. Based on the results of the focus group discussions and direct observation in the field can be understood that the dominant influence of human resource development to organizational performance by $86 \%$, this occurred because of human resource development effort is driven directly by the leadership of the hotel. Human resource development is actualized in the form of the practice of delegating tasks, engagement, recognition and awards to outstanding hotel employees are directly able to move all hotel employees to carry out the role and tasks in achieving the planned maximum target of the company.

\section{Research Limitations}

1) This study population already includes star hotels throughout the district / city in Bali, but the sample only includes III, VI and V star hotels, while star hotel I and II are not included as the study sample. To that end, the results of this study cannot complete hospitality management managerial portrait of star hotels in Bali.

2) This study only examines the relationship variables influence organizational performance with variable empowerment of human resources (HR), motivation, and organizational change. In fact, there are variables or other factors that potentially effect directly or indirectly on the performance of the organization, including the factor of quality of service, as well as factors related to policies on the construction of new hotels, policy on hotel rooms' requirement restriction, and policy determination of hotel room rates.

\section{Conclusion and Recommendations}

\section{Conclusion}

1) Empowering $\mathrm{HR}$ has positive and significant effect (according to the statistical indicators) on working motivation (83\%), changes in the organization $(77 \%)$ and organizational performance (by $86 \%$ ). The influence of human resource empowerment which is relatively high on working motivation, organizational change and organizational performance can be understood as management or operator of star hotels in Bali view that the management and human resource development becomes the main thing. Human resource development is done through improving the capacity and skills of hotel employees through training conducted consistently and continuously.

2) Working motivation has positive and significant effect on organizational changes (by $40 \%$ ), and the performance of organizations $(36 \%)$ of hotel business in Bali. Working motivation influence on the performance of the organization is relatively small $(36 \%)$ as motivation as a natural thing to manage employee morale. However, attempts to reward, career development plan can be implemented to maintain hotel employee motivation.

3) Changes in organization positively and significantly affect the performance of the hotel business organization in Bali (24\%). Although it is not the dominant factor, organizational change is still needed to support organizational performance improvement in hotel business in Bali.

4) The performance of the hotel business organization in Bali is affected by the human resource development (by 86\%), motivation $(36 \%)$, and organizational change (24\%). Human resource development is the most dominant influence on the performance organization, of the effect of working motivation and organizational change. 


\section{Recommendations}

\section{1) Recommendations for Management and Hotel Owner}

a) The variable of human resource development has the strongest influence to support the improvement of the performance of the organization, followed by variable changes in organization and working motivation. To that end, human resource development indicators can be used as a priority by the management in improving organizational performance in star hotels in Bali.

b) Empowerment of human resources and efforts to increase motivation to work is expected to improve quality service to hotel guests. Every hotel employee is expected to perform as well as a sales interpersonal communication that is able to understand the character and culture of hotel guests so that quality services provided will be fruitful for the satisfaction of hotel customers.

c) Efforts to improve organizational performance of star hotels business in Bali is supported by (1) an adequate factor of hotel facilities such as standard size hotel rooms (standard size of star hotel rooms at least 28 square meters), the avilable of pool, meeting room; (2) Factor of hotel location which situated near to the objects and tourism suporting facilities such as bars, restaurants, shopping archades, etc.

d) Most hotel consumers have determined the choice of accommodation through online services. To that end, the development of marketing systems of star hotel accommodation services online (ecommerce) should be developed.

e) Performance (achievements occupancy) of star hotels in Badung in the last three years (2010 to 2014) is quite high, around 60\% to $80 \%$ and still to be improved. In an effort to anticipate the competition among service providers star accommodation in Bali are increasingly stringent, the hotel management can implement dynamic pricing strategies in determining the price of the hotel room as enacted by some star hotels in Bali.

\section{2) Recommendations for Policy Holders}

a) Develop policies related to standards of competence, namely the certification of human resources for tourism personnel (hospitality). Certification of hospitality is necessary to support reliable human resource development efforts in the field of services of star hotel accommodations in Bali.

b) Restrictions on building new hotels and the number of hotel rooms are necessary for the hotel business in Bali can be run healthily.

c) In an effort to reduce unfair competition between service providers of accommodation services, standardization of prices (tariffs) of hotel room in Bali need to be developed.

\section{3) Recommendations for Academic Institutions/Universities}

a) Support the development of training model (training) of human resources of star hotels in Bali.

b) Develop module concerning the standardization of service quality of star hotel as a guideline for the management / operator of the hotel.

c) Develop module / curriculum that are used as a reference of education / training for capacity building and skills of human resource hospitality in Bali.

d) Conducting studies / advanced research on organizational performance of star hotels in Bali, particularly in relation to government policy factors on restrictions of building new hotels / number of hotel rooms, the determination of rates of hotel rooms, as well as studies related to the effectiveness of human resource development, motivation in improving star and non-stars hotel performance in Bali. 


\section{References}

Alwi, S. (2001) 'Manajemen Sumber Daya Manusia Strategi Keunggulan Kompetitif', Yogyakarta: BPFE.

Arimbawa, K. M. and Dewi, A. A. S. K. (2013) 'Pengaruh Budaya Organisasi, Gaya Kepemimpinan, dan Motivasi Kerja Terhadap Kinerja Karyawan Pada Hotel Jimbaran Puri Bali', EJurnal Manajemen Universitas Udayana, 2(12).

Brahmasari, I. A. (2004) 'Pengaruh variabel budaya perusahaan terhadap komitmen karyawan dan kinerja perusahaan kelompok penerbitan pers Jawa Pos'. Universitas Airlangga.

Chew, M. M. M., Cheng, J. S. L. and PetrovicLazarevic, S. (2006) 'Managers'role in Implementing Organizational Change: Case of The Restaurant Industry in Melbourne', Journal of Global Business and Technology. Global Business and Technology Association, 2(1), p. 58.

Gibson, J. L. et al. (1994) Organisasi: perilaku, struktur, proses. Penerbit Erlangga.

Hannan, M. T. and Freeman, J. (1984) 'Structural inertia and organizational change', American sociological review. JSTOR, pp. 149-164.

Hasibuan, M. S. P. (1990) Manajemen sumber daya manusia: dasar dan kunci keberhasilan. Haji Masagung.

Jarrar, Y. F. and Zairi, M. (2002) 'Employee empowerment-a UK survey of trends and best practices', Managerial Auditing Journal. MCB UP Ltd, 17(5), pp. 266-271.

Kotter, J. P. and Cohen, D. S. (2002) The heart of change: Real-life stories of how people change their organizations. Harvard Business Press.

http://ojs.unud.ac.id/index.php/eot
Lam, W. F. et al. (2011) 'The impacts of organizational change towards employees 'performance in banking industry.' UTAR.

Lashley, C. (1999) 'Employee empowerment in services: a framework for analysis', Personnel Review. MCB UP Ltd, 28(3), pp. 169-191.

Lindner, J. R. (1998) 'Understanding Employee Motivation', Journal of Extension, 36(3).

Luekitinan, W. (2014) 'The Relationship between Structural Empowerment and Job Satisfaction: Case Study of a Thai Auto Mobile Company', in Proceedings of 26th International Business Research Conference 7-8 April 2014.

McClelland, D. C. (1973) 'Testing for competence rather than for" intelligence.", American psychologist. American Psychological Association, 28(1), p. 1.

Muogbo, U. S. (2013) 'The impact of employee motivation on organisational performance (a study of some selected firms in anambra state nigeria)', The international journal of engineering and science, 2(7), pp. 70-80.

Nawawi, H. (2005) 'Manajemen Sumber Daya Manusia untuk bisnis yang kompetitif', Cetakan Keempat. Penerbit Gajah Mada University Press: Yogyakarta.

Noe, R. A. et al. (2003) Gaining a competitive advantage. Irwin: McGraw-Hill.

Rachmawati, I. K. (2008) Manajemen Sumber Daya Manusia. Edisi Pertama. Yogyakarta: CV. Andi Offset.

Ramlall, S. (2004) 'A review of employee motivation theories and their implications for employee retention within organizations', Journal of American Academy of Business. Cambridge, 5(1/2), pp. 52-63. 
Rispati, Hadi, F. and Rodhiyah (2013) 'Pengaruh Pelatihan Kerja Dan Motivasi Terhadap Kinerja Karyawan (Studi Kasus Pada Karyawan Hotel Grasia Semarang)', Diponegoro Journal Of Social And Politic Tahun, pp. 1-8.

Robbins, S. P. (2003) Perilaku organisasi. Jakarta: Salemba Empat.

Rokhman, W. (2002) 'Paradigma Baru MSDM: Pemberdayaan', Edisi Kedua, Amara Books, Jakarta.

Rose, R. C. and Kumar, N. (2006) 'The influence of organizational and human resource management strategies on performance', Performance improvement. Wiley Online Library, 45(4), pp. 18-24.

Rowley, C. and Jackson, K. (2012) Manajemen Sumber Daya Manusia. Jakarta: Raja Grafindo Persada.

Saydam, G. D. (2005) 'Manajemen Sumber Daya Manusia Suatu Pendekatan Mikro'. Djambatan, Jakarta.

Sedarmayanti (2001) Manajemen Sumber Daya Manusia, Reformasi Birokrasi dan Manajemen Pegawai Negeri Sipil (Cetakan Pertama). Bandung: Penerbit Refika Aditama.

Sobirin, A. (2005) 'Meraih Keunggulan Melalui Pengintegrasian Sumber Daya Manusia dan Perencanaan Strategik', Edisi Khusus Jurnal Siasat Bisnis On Human Resources.

Stewart, J. and O'Donnell, M. (2007) 'Implementing change in a public agency: Leadership, learning and organisational resilience', International Journal of Public Sector Management. Emerald Group Publishing Limited, 20(3), pp. 239251.
Suaedi, F. (2005) 'Pengaruh Struktur Organisasi, Budaya Organisasi, Kepemimpinan, Aliansi Strategis Terhadap Inovasi Organisasi dan Kinerja Organisasi Hotel Bintang Tiga di Jawa Timur', Ilmu Administrasi Negara FISIP Unair.

Sutawa, G. K. (2012) 'Issues on Bali tourism development and community empowerment to support sustainable tourism development', Procedia economics and finance. Elsevier, 4, pp. 413-422.

Suwatno, H. and Priansa, D. J. (2011) 'Manajemen SDM dalam organisasi Publik dan Bisnis', Bandung: Alfabeta.

Taplin, I. M. (2006) 'Strategic change and organisational restructuring: How managers negotiate change initiatives', Journal of International Management. Elsevier, 12(3), pp. 284-301.

Thomas, O. O. (2014) 'Change Management and its Effects on Organizational Performance of Nigerian Telecoms Industries: Empirical Insight from Airtel Nigeria', International Journal of Humanities Social Sciences and Education. Citeseer, 1(11), pp. 170179.

Triatmanto, B. et al. (2010) 'Peran Pemberdayaan Sumber Daya Manusia dalam Peningkatan Kinerja Organisasi melalui Perubahan dan Resiliensi Organisasi (Studi pada Industri Perhotelan di Jawa Timur)', Jurnal Aplikasi Manajemen-Journal of Applied Management, 8(4), pp. 951960.

Usman, H. (2006) 'Manajemen: teori, praktik, dan riset pendidikan', Jakarta: Bumi Aksara. 